\title{
Sustainabe
}

LPM IAIN Syaikh Abdurrahman Siddik Bangka Belitung

https://jurnal.lp2msasbabel.ac.id/index.php/sus ISSN 2655-0695 (Online)

\section{Penerapan Model Project Based Learning Untuk Meningkatkan Pekerjaan Dasar Elektromekanik Siswa Kelas X TITL SMKN 1 Maumere}

\author{
Application of Project-Based Learning Model to Improve Basic Electromechanical Work at \\ Class X TITL SMKN 1 Maumere
}

Yakobus Mbasa

SMK Negeri 1 Maumere, Indonesia

Keywords

Project Based

Learning

Learning Outcomes

\begin{abstract}
This research aimed to improve learning outcomes of Electromechanical Works Association through application of the model project based learning at class X TITL SMKN 1 Maumere. The subjects of this study were students of class X TITL SMK Negeri 1 Maumere academic year 2018/2019. The number of student were 35 students The method used in this research was a classroom action research (PTK). It was conducted in two cycles using a fourstage, among others: the planning, implementation, observation and reflection stages. The method that is used to collect data was testing and observation. The research instrument that is used in this research were the test result of learning, observation sheets and sheet performance. The results of this study showed that application of the model project based learning could improve student learning outcomes. Results of this study were: the increase in the average student learning outcomes, from 77.33 at 80.35 on the first cycle to the second cycle (an increase of 3:02). In addition there was also increasing in classical completeness, from $71.42 \%$ in the first cycle to $88.57 \%$ in the second cycle (increasing of 17:15\%). Based on the results of this study was concluded that student learning outcomes in learning basic electromechanical work could be increased through a model of project-based learning
\end{abstract}

\begin{abstract}
Abstrak
Penelitian ini bertujuan untuk meningkatkan hasil belajar Pekerjaan Dasar Elektromekanik melalui penerapan model project based learning pada siswa kelas X TITL SMKN 1 Maumere. Subyek penelitian ini adalah siswa kelas X TITL SMKN 1 Maumere tahun ajaran 2018/2019, dengan jumlah siswa sebanyak 35 siswa. Metode yang digunakan pada penelitian ini adalah Penelitian Tindakan Kelas (PTK) yang dilaksanakan dalam dua siklus menggunakan empat tahap, antara lain: tahap perencanaan, tahap pelaksanaan, tahap observasi dan refleksi. Metode yang digunakan untuk mengumpulkan data adalah metode tes dan observasi. Instrumen penelitian yang digunakan adalah tes hasil belajar, lembar observasi dan lembar unjuk kerja. Dari hasil penelitian dapat disimpulkan bahwa penerapan model project based learning dapat meningkatkan kemampuan hasil belajar siswa. Hasil penelitian ini adalah: terjadinya peningkatan rata-rata hasil belajar siswa, dari 77.33 pada siklus I menjadi 80.35 pada siklus II (terjadi peningkatan sebesar 3.02). Selain itu terjadi juga peningkatan ketuntasan klasikal, dari $71.42 \%$ pada siklus I menjadi $88.57 \%$ pada siklus II (terjadi peningkatan sebesar $17.15 \%$ ). Berdasarkan hasil penelitian dapat disimpulkan bahwa hasil belajar siswa pada pembelajaran pekerjaan dasar elektromekanik dapat meningkat

melalui model project based learning.
\end{abstract}

\section{Kata Kunci}

Pembelajaran Berbasis Projek Hasil Belajar

Korespondensi

Yakobus Mbasa

mansursaputraoo@gmail.com 


\section{Pendahuluan}

Pesatnya pembangunan yang disertai dengan perkembangan Ilmu Pengetahuan dan Teknologi dewasa ini perlu direspon oleh kinerja dunia pendidikan yang profesional dan memiliki mutu tinggi. Pembangunan di suatu negara tidak bisa mengabaikan kegiatan pendidikan. Masa depan suatu negara sangat ditentukan oleh bagaimana negara itu memperlakukan pendidikan. Dunia pendidikan yang bermutu diharapkan dapat mendukung tercetaknya generasi muda penerus bangsa yang cerdas, terampil dan berwawasan luas sehingga mampu bersaing di era global. Karena pada hakikatnya, fungsi pendidikan adalah untuk mengembangkan kemampuan serta meningkatkan mutu kehidupan dan martabat manusia (Undang-Undang Nomor 20 Tahun 2003). Keberhasilan pendidikan ditentukan oleh banyak aspek yang saling berkaitan. Secara falsafati, pendidikan adalah proses panjang dan berkelanjutan untuk mentransformasikan peserta didik menjadi manusia yang sesuai dengan tujuan penciptaannya, yaitu bermanfaat bagi dirinya, bagi sesama, bagi alam semesta, beserta segenap isi dan peradabannya. Pembelajaran adalah proses interaksi antara peserta didik dengan lingkungannya sehingga terjadi perubahan perilaku kearah yang lebih baik. Dalam proses pembelajaran prinsip utamanya adalah adanya proses keterlibatan seluruh atau sebagian besar potensi diri siswa (fisik dan nonfisik) dan kebermaknaannya bagi diri dan kehidupannya saat ini dan dimasa yang akan datang (life skill). Pendidikan merupakan salah satu aspek yang paling besar peranannya dalam kelangsungan hidup manusia dan perkembangan suatu bangsa. Menyadari akan pentingnya pendidikan, pemerintah telah melakukan berbagai upaya dalam meningkatkan mutu pendidikan.

Proses pendidikan yang baik adalah dengan memberikan kesempatan pada anak untuk kreatif. Itu harus dilakukan sebab pada dasarnya gaya berpikir anak tidak bisa diarahkan. Selain kurang kreatifnya para pendidik dalam membimbing siswa, kurikulum yang sentralistik membuat potret pendidikan semakin buram. Kurikulum hanya didasarkan pada pengetahuan pemerintah tanpa memperhatikan kebutuhan masyarakat. Lebih parah lagi, pendidikan tidak mampu menghasilkan lulusan yang kreatif. Ini salahnya, kurikulum dibuat di Jakarta dan tidak memperhatikan kondisi di masyarakat bawah. Jadi, para lulusan hanya pintar cari kerja dan tidak pernah bisa menciptakan lapangan kerja sendiri, padahal lapangan pekerjaan yang tersedia terbatas. Kualitas pendidikan Indonesia yang memprihatinkan, ini juga kesalahan negara yang tidak serius untuk meningkatkan kualitas pendidikan. Disinilah guru merupakan pihak yang paling banyak berhubungan dengan proses belajar mengajar di sekolah. Guru yang baik adalah guru yang peka terhadap perkembangan belajar dan prestasi anak didik di sekolah. Guru adalah orang yang terlibat langsung dalam kegiatan pembelajaran, sehingga dia dituntut untuk menelusuri berbagai kendala yang sedang dihadapi siswanya. Guru profesional memiliki pengetahuan yang luas serta dalam dari satuan pelajaran yang akan diajarkan serta penguasaan metodologi dalam arti memiliki pengetahuan konsep teoritik, mampu memilih metode yang tepat serta mampu menggunakan berbagai metode dalam proses belajar mengajar.

Sekolah Menengah Kejuruan atau yang disebut SMK adalah bagian terpadu dari Sistem Pendidikan Nasional, yang mempunyai peranan penting di dalam menyiapkan dan pengembangan Sumber Daya Manusia. Mata pelajaran pekerjaan dasar elektromekanik merupakan salah satu dari sejumlah mata pelajaran yang diajarkan di kelas X TITL SMK Negeriı Maumere. Sesuai dengan kurikulum SMK, pekerjaan dasar elektromekanik merupakan mata pelajaran tahap awal pengenalan siswa terhadap cara menyolder dan cara melarutkan pcb. Oleh sebab itu mata pelajaran ini sangat berperan penting bagi siswa untuk memiliki keterampilan dan di harapkan bisa menguasai setiap materi yang diberikan saat proses pembelajaran.

Proses pembelajaran di kelas ada beberapa masalah yang dihadapi oleh seorang guru. Kurangnya keaktifan siswa, kurangnya konsentrasi siswa, siswa suka mengganggu teman dan siswa kurang fokus dalam mengikuti proses pembelajaran secara tidak langsung akan mempengaruhi hasil belajar yang hendak dicapai. Tidak hanya itu pembelajaran yang monoton akan berdampak pada kejenuhan siswa dalam menerima mata pelajaran. Salah satu upaya yang dapat dilakukan guru guna meningkatkan meningkatan hasil belajar siswa, yaitu dengan menggunakan berbagai model pembelajaran terbaru yang sedang marak diterapkan oleh karangan-karangan guru kreatif. Sebaiknya guru menyadari bahwa model dalam pembelajaran dapat dikatakan sebagai suatu komponen yang turut berperan dalam keberhasilan 
belajar mengajar. Salah satu model yang cukup aktif untuk menunjang keberhasilan belajar siswa adalah model Project Based Learning. Model Project Based Learning adalah cara penyampaian bahan pengajaran dengan memberi kesempatan kepada siswa untuk belajar mengembangkan potensi intelektualnya dalam jalinan kegiatan yang disusunnya sendiri untuk menemukan sesuatu sebagai jawaban yang meyakinkan terhadap permasalahan yang dihadapkan kepadanya melalui proses pelacakan data dan informasi serta pemikiran yang logis, kritis dan sistematis. Model Project Based Learning ini makin lebih memberi peluang kepada siswa untuk terlibat secara aktif dalam pembelajaran walaupun guru masih menjadi kendali utama. Melatih siswa untuk berani mengemukakan atau menanyakan sesuatu yang menurutnya tidak/kurang jelas dan memungkinkan siswa untuk lebih kreatif dalam proses pembelajaran.

\section{Metode}

Jenis penelitian yang digunakan adalah penelitian tindakan kelas (PTK) atau class action research. Model yang dipilih pada penelitian ini adalah model Suharsimi Arikunto yang mengemukakan bahwa PTK dapat dirangkum secara garis besar sebagai berikut: bahwa terdapat empat pelaksanaan tahapan yang lazim dilalui yaitu, (1) perencanaan, (2) pelaksanaan, (3) pengamatan, dan (4) refleksi (Suharsimi Arikunto dalam Paizaluddin dan Ermalinda, 2014:33).

Perencanaan dilakukan dengan menyiapkan berbagai alat/media yang diperlukan pada pelaksanaan kegiatan siklus I. Menyiapkan Silabus mata pelajaran pekerjaan dasar elektromekanik. Guru sebagai peneliti menyusun Rencana Pelaksanaan Pembelajaran (RPP) tentang kerja proyek 2. Menyiapkan materi kerja proyek 2 yang akan diajarkan dan menyiapkan sarana dan prasarana yang diperlukan dalam proses pembelajaran penyolderan. Menyiapkan evaluasi yaitu berupa test sebanyak 25 soal untuk mengetahui hasil belajar materi pokok kerja proyek 2 pada mata pelajaran pekerjaan dasar elektromekanik. Melakukan pengenalan terhadap rencana penerapan model project based learning. Upaya yang dilakukan oleh guru sebagai peneliti untuk melakukan peningkatan yang diinginkan. Kegiatan yang dilakukan pada rancangan pelaksanaan ini adalah melaksanakan proses pembelajaran sesuai dengan rencana pelaksanaan pembelajaran (RPP) yang dibuat bersama yang disesuaikan dengan model project based learning.

Guru sebagai peneliti mengamati aktivitas siswa dalam mengikuti proses belajar menggunakan instrumen yang sudah dipersiakan sebelumnya. Setelah selasai proses belajar mengajar maka selanjutnya guru sebagai peneliti akan melakukan penilaian terhadap hasil proyek yang dibuat masing-masing individu. Dibawah ini akan di jelaskan tahapan-tahapan/sintaks dari model project based learning. Terdiri dari 6 fase pokok. Praproyek, tahapan ini merupakan kegiatan yang dilakukan guru di luar jam pelajaran. Pada tahap ini guru merancang deskripsi proyek, menyiapkan media dan berbagai sumber belajar, dan menyiapkan kondisi pembelajaran. Di dalam fase ini guru menyampaikan segala materi pembelajaran yang akan dipakai sebagai landasan dalam melakukan kegiatan praktik selama pelajaran berlangsung. Pertanyaan esensial, pada tahap ini siswa melakukan pengamatan terhadap obyek tertentu. Berdasarkan pengamatannya tersebut siswa mengidentifikasi masalah dan membuat rumusan masalah dalam bentuk pertanyaan. Permasalahan utama yakni cara menyolder yang baik. Pembelajaran dimulai dengan pertanyaan essensial, yaitu pertanyaan yang mendorong siswa untuk melakukan suatu aktivitas. Membuat desain dan jadwal pelaksanaan proyek, pada tahap ini siswa dengan guru mulai merancang proyek yang akan dibuat. Siswa dengan pendampingan dari guru membuat desain rencana proyek yang akan dilakukan. Setelah mendisain, Guru dan siswa secara kolaboratif menyusun jadwal pelaksanaan kegiatan pembelajaran. Memantau kegiatan pratikum, guru bertanggung jawab memantau kegiatan siswa selama meyelesaikan proyek untuk mengetahui kemajuan pelaksanaan proyek dan mengantisipasi hambatan yang dihadapi siswa. Menilai, penilaian dilakukan untuk mengatur ketercapaian standar, mengevaluasi kemajuan masing-masing siswa, memberi umpan balik tentang tingkat pemahaman yang sudah dicapai dan menjadi bahan pertimbangan dalam menyusun strategi pembelajaran berikutnya. Evaluasi, pada akhir pembelajaran, guru dan siswa melakukan refleksi terhadap aktivitas dan hasil proyek yang sudah dijalankan. Proses refleksi dilakukan secara individu maupun kelompok. Pascaproyek, pada tahap ini guru menilai, memberikan penguatan, masukan, dan saran perbaikan atas apa yang dikerjakan siswa. Guru menyimpulkan pembelajaran tentang menyolder. 
Selama pelaksanaan tindakan, guru sebagai peneliti mengamati kebiasaan-kebiasaan anak dalam belajar terutama kaitannya dengan keterampilan siswa dalam praktek, Guru melakukan pengamatan berkaitan dengan dampak yang ditimbulkan dengan menerapkan model project based learning. Pengamatan dilakukan secara terus menerus selama proses pembelajaran. Selain melakukan observasi, pada akhir siklus I dilakukan evaluasi. Evaluasi dilakukan untuk mengetahui hasil belajar siswa dengan menerapkan model project based learning. Hasil observasi dan evaluasi diperoleh pada siklus I dijadikan bahan untuk melakukan refleksi dalam menentukan tindakan siklus selanjutnya. Disamping itu akan dilakukan langkah-langkah perbaikan sehingga hasil belajar dapat dicapai. Pada tahap ini guru menganalisis kendala-kendala yang di alami siswa dalam proses pembelajaran dan mencari apa saja faktor-faktor penyebabnya yang nantinya hasil dari diskusi tersebut digunakan sebagai bahan pertimbangan atau penyempurnaan untuk tahapan-tahapan pada siklus II. Perencanaan dilakukan dengan menyiapkan berbagai alat/media yang diperlukan pada pelaksanaan kegiatan siklus II yang disesuaian dengan hasil refleksi siklus I. Menyiapkan Silabus mata pelajaran pekerjaan dasar elektromekanik. guru menyusun Rencana Pelaksanaan Pembelajaran (RPP) siklus II tentang kerja proyek 3. Menyiapkan materi kerja proyek 3 yang akan diajarkan dan menyiapkan sarana dan prasarana yang diperlukan dalam proses pembelajaran melarutkan PCB polos. Menyiapkan evaluasi yaitu berupa test sebanyak 25 soal untuk mengetahui hasil belajar materi pokok kerja proyek 3 pada mata pelajaran pekerjaan dasar elektromekanik. Kelima, kembali melakukan pengenalan terhadap rencana penerapan model project based learning.Pada tahap pelaksanakan siklus II ini.

Proses pembelajaran mengacu pada rencana pelaksanaan pembelajaran (RPP) yang telah disusun berdasarkan model project based learning untuk meningkatkan hasil belajar pekerjaan dasar elektromekanik.Guru mengamati aktivitas siswa dalam mengikuti proses belajar menggunakan instrumen yang sudah dipersiakan sebelumnya. Setelah selasai proses belajar mengajar maka selanjutnya dalam melakukan penilaian terhadap hasil project yang dibuat masing-masing individu. Selanjutnya guru mengevaluasi pengusaan materi melalui pemberian kuis secara lisan. Terdiri dari 6 fase pokok. Praproyek, tahapan ini merupakan kegiatan yang dilakukan guru di luar jam pelajaran. Pada tahap ini guru merancang deskripsi proyek, menyiapkan media dan berbagai sumber belajar, dan menyiapkan kondisi pembelajaran. Di dalam fase ini guru menyampaikan segala materi pembelajaran yang akan dipakai sebagai landasan dalam melakukan kegiatan praktik selama pelajaran berlangsung. Pertanyaan esensial, Pada tahap ini siswa melakukan pengamatan terhadap obyek tertentu. Berdasarkan pengamatannya tersebut siswa mengidentifikasi masalah dan membuat rumusan masalah dalam bentuk pertanyaan.

Permasalahan utama yakni cara menyolder yang baik. Pembelajaran dimulai dengan pertanyaan esensial, yaitu pertanyaan yang mendorong siswa untuk melakukan suatu aktivitas. Membuat desain dan jadwal pelaksanaan proyek, pada tahap ini siswa dengan guru mulai merancang proyek yang akan dibuat. Siswa dengan pendampingan dari guru membuat desain rencana proyek yang akan dilakukan. Setelah mendisain, Guru dan siswa secara kolaboratif menyusun jadwal pelaksanaan kegiatan pembelajaran. Memantau kegiatan pratikum, guru bertanggung jawab memantau kegiatan siswa selama meyelesaikan proyek untuk mengetahui kemajuan pelaksanaan proyek dan mengantisipasi hambatan yang dihadapi siswa. Menilai, penilaian dilakukan untuk mengatur ketercapaian standar, mengevaluasi kemajuan masing-masing siswa, memberi umpan balik tentang tingkat pemahaman yang sudah dicapai dan menjadi bahan pertimbangan dalam menyusun strategi pembelajaran berikutnya. Evaluasi, pada akhir pembelajaran, guru dan siswa melakukan refleksi terhadap aktivitas dan hasil proyek yang sudah dijalankan. Proses refleksi dilakukan secara individu maupun kelompok. Pascaproyek, pada tahap ini guru menilai, memberikan penguatan, masukan, dan saran perbaikan atas apa yang dikerjakan siswa. Guru menyimpulkan pembelajaran tentang menyolder.

Selama pelaksanaan tindakan, peneliti mengamati kebiasaan-kebiasaan anak dalam belajar terutama kaitannya dengan keterampilan siswa dalam praktek, guru melakukan pengamatan berkaitan dengan dampak yang ditimbulkan dengan menerapkan model project based learning. Pengamatan dilakukan secara terus menerus selama proses pembelajaran. Selain melakukan observasi, pada akhir siklus II dilakukan evaluasi. Evaluasi dilakukan untuk mengetahui hasil belajar siswa dengan menerapkan model project based learning. Hasil observasi dan evaluasi diperoleh pada siklus II dijadikan bahan 
diskusi bersama guru mitra yang memegang mata pelajaran pekerjaan dasar elektromekanik.

Pada tahap ini guru sebagai peneliti menganalisis kembali untuk mendapatkan kesimpulan bahwa pada penelitian ini dapat meningkatkan hasil belajar siswa di kelas X TILTL. Dan diharapkan pada akhir siklus II ini hasil belajar siswa pada Mata Pelajaran Pekerjaan Dasar elektromekanik kelas X TITL dapat meningkat.

Metode pengumpulan data merupakan cara untuk mengumpulkan data yang digunakan dalam penelitian. Penggunaan metode pengumpulan data ini dilakukan untuk mendapatkan data yang tepat. Metode pengumpulan yang digunakan pada penelitian ini adalah tes pilihan ganda (kognitif), observasi penilaian sikap (afektif) dan penilaian keterampilan (psikomotor). Pada penelitian ini data yang dikumpulkan untuk dianalisis adalah data hasil belajar pekerjaan dasar elektromekanik dengan materi tentang kerja proyek 2 dan kerja proyek 3. Berdasarkan Permendikbud no. 66 tahun 2013 tentang standar penilaian, maka pada penilaian kurikulum 2013 menggunakan penilaian autentik pada proses dan hasil yang mencakup 3 aspek penilaian, yaitu pengetahuan (kognitif), sikap (afektif) dan keterampilan (psikomotor). Data terkait pengetahuan siswa dikumpulkan dengan instrumen berupa tes yang diberikan disetiap akhir siklus, data dari sikap siswa dikumpulkan dengan instrumen berupa observasi penilaian sikap dan data keterampilan siswa dikumpulkan dengan instrumen berupa observasi (pengamatan) praktek.

Tes merupakan alat pengukur data yang berharga dalam penelitian. Teknik pengumpulan data penilaian kognitif pada penelitian ini menggunakan metode tes pilihan ganda. Menurut Arikunto (2013:179) tes objektif atau pilihan ganda adalah tes yang dalam pemerikaannya dapat dilakukan secara objektif. Tes pilihan ganda terdiri atas sebuah pernyataan atau kalimat yang belum lengkap, kemudian diikuti oleh sejumlah pernyataan atau bentuk yang dapat digunakan untuk melengkapinya. Dari sejumlah "pelengkap" tersebut hanya satu yang tepat, yang lain merupakan pengecoh.

Untuk data nilai sikap siswa, dinilai melalui observasi penilaian sikap siswa pada saat proses belajar mengajar. Bentuk penilaian berupa nontes dapat digunakan untuk mengukur domain afektif. Dalam penelitian ini, untuk penilaian afektif menggunakan instrumen berupa observasi penilaian afektif. Menurut Sugiyono (2014:203) teknik pengumpulan data dengan observasi digunakan bila, penelitian berkenaan dengan prilaku manusia, proses kerja, gejala- gejala alam dan bila responden yang diamati tidak terlalu besar. Ada beberapa macam teknik skala yang bisa digunakan dalam instrumen observasi penilaian afektif, salah satunya adalah skala Linkert.

Penilaian psikomotor dilakukan terhadap hasil-hasil belajar yang berupa penampilan. Penilaian psikomotor dapat dilakukan dengan tes saat, praktik. Dalam penelitian ini, teknik pengumpulan data yang digunakan yaitu tes praktik. Tes praktek adalah penilaian yang dilakukan dengan mengamati kegiatan peserta didik dalam melakukan sesuatu pada saat proses pembelajaran. Instrumen penilaian yang digunakan untuk unjuk kerja adalah lembar observasi. Instrumen yang digunakan untuk mengukur psikomotor biasanya berupa matriks. Kebawah menyatakan perincian aspek keterampilan yang akan diukur dan yang ke kanan menunjukan besarnya skor yang dapat dicapai. (Arikunto, 2013:198)

Instrumen penelitian adalah suatu alat yang digunakan mengukur fenomena alam maupun sosial yang diamati. Secara spesifik semua fenomena ini disebut variabel penelitian" (Sugiono, 2014:148). Instrumen penelitian yang dipergunakan dalam penelitian ini adalah tes objektif dalam bentuk pilihan ganda (kognitif), observasi penilaian sikap (afektif) dan observasi penilaian unjuk kerja (psikomotor) untuk mengukur hasil belajar pekerjaan dasar elektromekanik. Salah satu tujuan dibuatnya instrumen adalah untuk memperoleh data dan informasi yang lengkap mengenai hal-hal yang ingin dikaji dalam penelitian ini. Untuk mendapatkan tes hasil belajar mempunyai kualitas yang baik maka sebelum tes dipergunakan, terlebih dahulu dilakukan validasi instrumen yang terdiri dari uji validitas, uji daya beda, uji indeks kesukaran, uji reliabilitas dan efektifitas pengecoh. Uji instrumen penelitian ini dilakukan pada siswa kelas X TITL SMKN 1 Maumere dengan jumlah siswa sebanyak 35 orang. Dalam penelitian ini, untuk menganalisis data menggunakan metode analisis statistik deskriptif baik deskriptif kuantitatif maupun kualitatif. Menurut Agung (2010:8) analisis deskriptif kuantitatif adalah suatu cara pengolahan data yang dilakukan dengan jalan sistematis dalam bentuk angka-angka dan atau 
persentase mengenai suatu objek yang diteliti, sedangkan analisis kualitatif adalah suatu cara analisis/pengolahan data dengan jalan menyusun secara sistematis dalam bentuk narasi atau kalimat/kata-kata mengenai suatu objek. Mengumpulkan dan mengkaji data hasil belajar melalui tes kognitif, observasi penilaian afektif dan observasi penilaian unjuk kerja psikomotor. Hasil belajar siswa dalam pembelajaran secara klasikal di harapkan tercapai 85\%. Bilamana indikator keberhasilan tersebut telah terpenuhi atau target tercapai maka siklus penelitian dihentikan.

\section{Hasil dan Diskusi}

Penelitian tindakan kelas ini dilaksanakan berdasarkan prosedur penelitian yang telah dirancang di bab III. Penelitian ini dilakukan dalam dua siklus, siklus I dan siklus II. Pada bab IV ini akan dibahas secara berturut-turut tentang data hasil uji instrumen penelitian, hasil tes pengetahuan awal (pre test), hasil penelitian siklus I, hasil penelitian siklus II dan pembahasan. Penelitian ini dilaksanakan di kelas X TITL SMKN 1 Maumere dengan jumlah siswa sebanyak 35 orang Data yang dikumpulkan dalam penelitian ini yaitu data mengenai hasil belajar pekerjaan dasar elektromekanik dengan materi pokok kerja proyek 2 dan kerja proyek 3 dengan penerapan model project based learning. Data yang berupa hasil belajar yang telah dikumpulkan ini akan dianalisis sesuai dengan teknik analisis yang telah ditentukan. Hasil analisis data hasil belajar pekerjaan dasar elektromekanik siswa dipaparkan sebagai berikut.

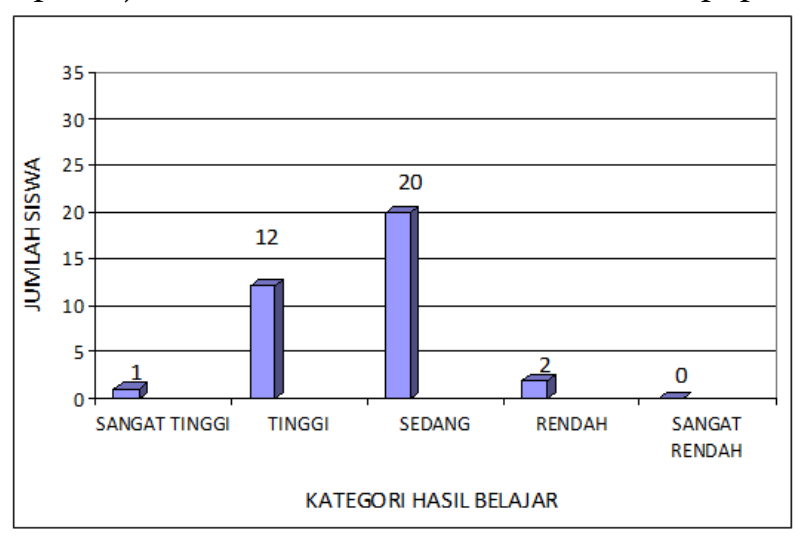

Gambar 1. Hasil Belajar Siklus 1

Dari 35 siswa yang mengikuti tes pengetahuan awal (pre test) diperoleh jumlah skor seluruh siswa adalah 2485 dan nilai rata-rata hasil belajarnya adalah 71 dengan ketuntasan klasikal mencapai $51.42 \%$, dari data tersebut dapat diketahui bahwa ketuntasan klasikal hasil tes pengetahuan awal siswa (pre test) belum mencapai $85 \%$, dimana hanya 18 orang siswa yang tuntas sedangkan 17 orang siswa tidak tuntas. Sehingga perlu dilakukan tindakan siklus I yang diharapkan dapat meningkatkan hasil belajar siswa kelas X TITL di SMK Negeri 1 Maumere. Dari 35 siswa yang mengikuti tes siklus I diperoleh 25 siswa yang tuntas dan 10 siswa tidak tuntas dengan jumlah skor seluruh siswa adalah 2706.67 dan nilai rata-rata hasil belajarnya adalah 77.33 serta ketuntasan klasikal mencapai $71.42 \%$.

Dari 35 siswa yang mengikuti tes siklus II diperoleh 31 siswa tuntas dan 4 siswa tidak tuntas dengan jumlah skor seluruh siswa adalah 2812.33 dan nilai rata-rata hasil belajarnya adalah 80.35 serta ketuntasan klasikal mencapai 88.57\%. 


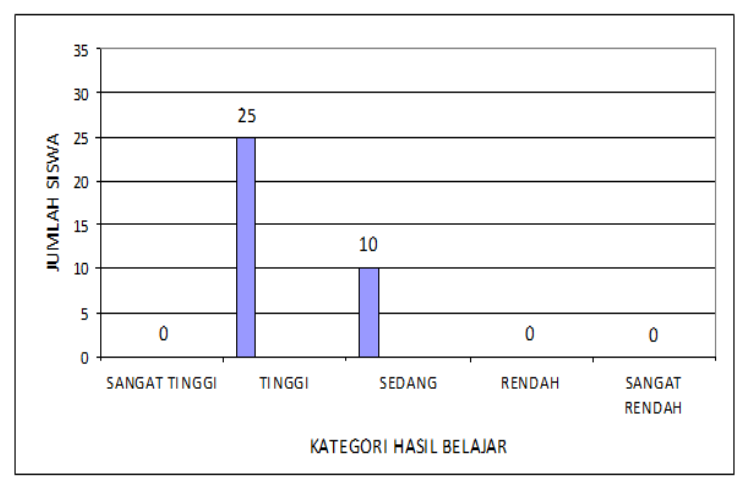

Gambar 2. Hasil Belajar Siklus 2

Tabel 1. Hasil Belajar Pre Test, Siklus 1, Siklus 2

\begin{tabular}{lccccccc}
\hline $\begin{array}{l}\text { Tindakan } \\
\text { Klasikal }\end{array}$ & Siswa & KKM & Jumlah & \multicolumn{2}{l}{ Rata-rata Ketuntasan } & Tuntas & Tidak Tuntas \\
\hline Pre-test & 35 & 75 & 2485 & 71 & $51.42 \%$ & 18 & 17 \\
Siklus 1 & 35 & 75 & $\mathbf{2 7 0 6 . 6 7}$ & 77.33 & $71.42 \%$ & 25 & 10 \\
Siklus 2 & 35 & 75 & $\mathbf{2 8 1 2 . 3 3}$ & 80.35 & $88.57 \%$ & 31 & 4 \\
\hline
\end{tabular}

Pada penelitian ini yang diukur adalah hasil belajar pekerjaan dasar elektromekanik melalui penerapan model project based learning dengan materi pokok kerja proyek 2 (Solder) dan kerja proyek 3 (PCB). Penelitian ini dirancang melalui dua siklus yang terdiri dari siklus I dan Siklus II. Pada siklus I terdiri dari perencanaan, pelaksanaan, pengamatan dan refleksi siklus I. Apabila pada siklus I belum mencapai kreteria ketuntasan yang ditetapkan maka akan dilanjutkan ke siklus II yang juga terdiri dari perencanaan, pelaksanaan, pengamatan dan refleksi siklus II.

Pembelajaran dengan menggunakan model project based learning dapat meningkatkan kemampuan hasil belajar siswa. Dengan menerapkan model project based learning, dimana pembelajaran dimulai dengan memberikan pertanyaan terbuka kepada siswa. Pertanyaan terbuka ini diharpakan siswa mampu menjawab permasalahan tersebut dengan banyak cara sehingga mangundang kemampuan hasil belajar siswa untuk menemukan cara yang baru. Pembelajaran seperti ini diharapkan dapat membuat siswa lebih kreatif dalam dan berguna bagi siswa dalam menyelesaikan masalah. Sebab dalam praktiknya siswa harus terlebih dahulu mengidentifikasi informasi-informasi yang ada dalam materi. Lalu menganalisisnya dan kemudian siswa memodifikasi informasi yang ada atau diketahui tersebut hingga menjadi jawaban yang diselesaikan melalui ide-ide yang muncul.

Sebelum pelaksanaan siklus I dilakukan tes pengetahuan awal (pre test) untuk mengetahui sejauh mana kemampuan siswa dalam mata pelajaran pekerjaan dasar elektromekanik. Pemberian pre test dilakukan sebelum tindakan siklus I berisikan tentang rangkuman umum terkait materi pelajaran pekerjaan dasar elektromekanik. Dari 35 siswa yang mengikuti tes pengetahuan awal (pre test) diperoleh jumlah skor seluruh siswa adalah 2485 dan nilai rata-rata hasil belajarnya adalah 71 dengan ketuntasan klasikal mencapai $5 \mathbf{1 . 4 2} \%$, dari data tersebut dapat diketahui bahwa ketuntasan klasikal hasil tes pengetahuan awal siswa (pre test) belum mencapai $85 \%$, dimana hanya 18 orang siswa yang tuntas sedangkan 17 orang siswa tidak tuntas. Sehingga perlu dilakukan tindakan siklus I yang diharapkan dapat meningkatkan hasil belajar siswa.

Berdasarkan hasil penelitian terhadap pelajaran pekerjaan dasar elektromekanik dengan penerapan model project based learning, pada pelaksanaan tindakan siklus I pengkondisisan kelas belum berjalan dengan baik, masih terdapat siswa yang mengobrol, bermain bahkan berjalan-jalan di kelas. Beberapa siswa masih malu dan enggan bertanya untuk mengeluarkan pendapatnya. Dari 35 siswa yang mengikuti tes siklus I diperoleh 25 siswa yang tuntas dan 10 siswa tidak tuntas dengan jumlah skor 
seluruh siswa adalah 2706.67 dan nilai rata-rata hasil belajarnya adalah 77.33 serta ketuntasan klasikal mencapai $71.42 \%$. Karena hasil ketuntasan klasikal yang diperoleh pada siklus I belum mencapai target yang diharapkan yaitu $85 \%$, maka penelitian dilanjutkan ke siklus II dengan melakukan perbaikan perbaikan pembelajaran yang sesuai dengan kendala-kendala yang dihaapi pada siklus I.

Berdasarkan penerapan rancangan pada siklus II yang merupakan perbaikan dari tindakan pada siklus I, memberikan hasil berupa peningkatan hasil belajar yang cukup signifikan. Adapun peningkatan rata-rata hasil belajar siswa pada siklus II diperoleh 31 siswa tuntas dan 4 siswa tidak tuntas dengan jumlah skor seluruh siswa adalah 2812.33 dan nilai rata- rata hasil belajarnya adalah 80.35 serta ketuntasan klasikal mencapai 88.57\%. Dari paparan diatas secara umum telah mampu menjawab rumusan masalah dan mencapai tujuan yang diharapkan. Penelitian ini dapat dikatakan berhasil karena semua kriteria yang ditentukan telah terpenuhi. Hal ini menandakan bahwa dengan penerapan model project based learning dapat meningkatkan hasil belajar pekerjaan dasar elektromekanik siswa kelas $\mathrm{X}$ TITL tahun ajaran 2018/2019.

\section{Kesimpulan}

Berdasarkan hasil penelitian dan pembahasan yang telah diuraikan diatas, dapat disimpulkan beberapa hal sebagai berikut. Penerapan model project based learning pada pekerjaan dasar elektromekanik di kelas X TITL SMKN 1 Maumere dapat meningkatkan hasil belajar siswa, hal itu dapat dilihat dari peningkatan ketuntasan klasikal yang diperoleh sebelum diterapkannya model project based learning sebesar $51.42 \%$ sedangkan setelah diterapkannya model project based learning selama dua siklus didapat hasil yaitu pada siklus I ketuntasan klasikal didapat sebesar $71.42 \%$. dan pada akhir siklus II yang mana sebesar $88.57 \%$. Dengan peningkatan rata-rata hasil belajar siswa dari 77.33 pada siklus I menjadi 80.35 pada Siklus II.

\section{Referensi}

Agung, A. A. Gede. 2010. Penelitian Tindakan Kelas (Teori dan Analisis Data dalam PTK). Makalah (tidak diterbitkan). Jurusan Pendidikan Guru Sekolah Dasar, FIP Undiksha. Singaraja.

Paizaluddin, dan Ermalinda. 2014. Penelitian Tindakan Kelas (Classroom Action Research) Panduan Teoritis dan Praktis. Bandung: Alfabeta.

Permendikbud no. 66 tahun 2013 tentang Standar Penilaian. Available: https://doc-oo34docs.googleusercontent.com/docs/securesc/haoro937gcuc7l7deffksulhg5h7mbp1

/icu5f4iqo9648tinph5vaea21d625uga/1430215200000/o9304581819309466231/*/oBwo1 x9JMm6NOVkVKdXVHMnBhRnlSalZOMmRhTDBzVlo5aHlz?e=download (diunduh pada tanggal 20 Mei 2015).

Rusman. 2013. Model-model Pembelajaran Mengembangkan Profesionalisme Guru, Edisi Kedua. Depok: PT Rajagrafindo Persada. Edisi 2.

Sugiyono. 2014. Metode Penelitian Pendidikan Pendekatan Kuantitatif, Kualitatif dan RED. Bandung: Alfabeta.

Suharsimi, Arikunto. 2013. Dasar-dasar Evaluasi Pendidikan. Jakarta : Bumi Aksara

Sutirman. 2013. Media E Model-model Pembelajaran Inovatif. Yogyakarta : Graha Ilmu.

Undang-Undang Sistem Pendidikan Nasional No. 20 tahun 2003 tentang pendidikan. Available: http://www.kemenag.go.id/file/dokumen/UU2003.pdf (diunduh tanggal 7 September 2014). 